VITAE, REVISTA DE LA FACULTAD DE CIENCIAS FARMACÉUTICAS Y ALIMENTARIAS

ISSN 0121-4004 / ISSNe 2145-2660. Volumen 27 Number 1, Year 2020, id-338150

Universidad de Antioquia, Medellín, Colombia.

DOI: http://dx.doi.org/10.17533/udea.vitae.v27n1a02

\title{
ANTIMICROBIAL ACTIVITY OF A SYNTHETIC BACTERIOCIN FOUND IN THE GENOME OF LACTOBACILLUS CASEI ON THE MICROBIOTA OF ANTIOQUIAN SOFT CHEESE (QUESITO ANTIOQUEÑO)
}

\author{
ACTIVIDAD ANTIMICROBIANA DE UNA BACTERIOCINA SINTÉTICA PROVENIENTE \\ DEL GENOMA DE LACTOBACILLUS CASEI SOBRE LA MICROBIOTA \\ DE QUESITO ANTIOQUEÑO
}

Laura BOLÍVAR PARRA ${ }^{1}{ }^{\mathbb{D}}$, Paula Andrea GIRALDO HINCAPIÉ ${ }^{\mathbb{D}}$, Olga Inés MONTOYA CAMPUZANO ${ }^{\mathbb{D}}$

Received: April 01 of 2019. Approved: April 05 of 2020.

\begin{abstract}
Background: Lactic Acid Bacteria (LAB) are of special interest in the food industry due to their ability to produce metabolites. Among them, bacteriocins, which can inhibit the growth of altering microorganisms, and pathogens in a wide variety of foods, are considered safe for human consumption and are used as preservatives. Objectives: Evaluate the effect of a bacteriocin found by in silico methods on the microbiota present in Antioquian soft cheese. Methods: In this research, we design a synthetic bacteriocin, called Bac 22, found in the genome of Lactobacillus casei using the genomic mining methodology and bioinformatics tools. We also conducted a preliminary biological and hemolytic activities studies of the Bac 22 toward the microbiota present in the Antioquian soft cheese (Quesito Antioqueño). Results: The bacteriocin Bac 22 at a concentration of $100 \mu \mathrm{M}$ presented a hemolytic capacity lower than $1 \%$ and reduced the CFU / g of total coliforms significantly when added to Antioquian soft cheese for eight days. Conclusions: The Bac 22 demonstrated a positive potential effect over the shelf life of a dairy product, such as the Antioquian soft cheese.
\end{abstract}

Keywords: computational biology, peptides, food preservation, in silico

\section{RESUMEN}

Antecedentes: Las Bacterias Ácido Lácticas (BAL) son de especial interés para la industria alimentaria por su capacidad de producir metabolitos entre ellos, las bacteriocinas que inhiben el crecimiento de microorganismos alterantes y de patógenos en una amplia variedad de alimentos, se consideran seguras para el consumo humano y son utilizadas como conservantes. Objetivo: Se evaluó el efecto de una bacteriocina encontrada por métodos in silico sobre la microbiota presente en Quesito Antioqueño. Métodos: se evaluó la actividad hemolítica de Bac 22, una bacteriocina sintética encontrada en el genoma de Lactobacillus casei a partir de minería genómica y de herramientas bioinformáticas, y se realizó un estudio preliminar de la actividad biológica de Bac 22 sobre la microbiota presente en el Quesito Antioqueño. Resultados: Bac 22 a

Universidad Nacional de Colombia, Sede Medellín, Medellín, Colombia

Corresponding author: 1bolivarp@unal.edu.co 
una concentración de $100 \mu \mathrm{M}$ presentó una capacidad hemolítica menor al 1\%, y redujo significativamente el número de UFC/g en coliformes totales al adicionarse en el Quesito Antioqueño durante ocho días. Conclusiones: Bac 22 muestra un efecto potencial sobre la vida útil del mismo.

Palabras clave: biología computacional, péptidos, conservación de alimentos, in silico

\section{INTRODUCTION}

Foodborne diseases (FBD) are a major public health concern and a significant cause of morbidity due to the high incidence in the world. According to the World Health Organization (WHO) (1), FBD affects individuals of all ages, particularly children (under five years) and people living in low-income regions. It is estimated that each year, nearly 600 million people get sick by eating contaminated food, and 420,000 dies from the same cause. In Colombia, in 2015, a total of 10,243 cases of FBDs and waterborne diseases were reported to the National Public Health Surveillance System (SIVIGILA) (2), of which 1,434 cases were registered in the Antioquia department, being Medellin the city with the most significant number of reported cases (3).

Protein-rich foods like milk are more susceptible to microbial contamination. Therefore, it is necessary to evaluate its microbiological quality as well as its derivatives products. Traditionally crafted Soft Cheese is an essential part of the Antioquian basic basket, with a production of 1,608,914 kg/year (4). The Antioquian Soft Cheese is a fatty cheese of high humidity (aw of 0.98 ) and relatively elevated $\mathrm{pH}$. It is consumed fresh and is made from whole or semi-skimmed sanitized cow's milk (5). This cheese has a shelf life of approximately one week and must be kept at refrigeration temperature (6). Its physicochemical characteristics are ideal for the growth of altering microorganisms and especially pathogens such as Listeria monocytogenes, Escherichia coli, Salmonella, and Staphylococcus aureus (6). It is an extremely perishable product that, in some cases, when is elaborated in an artisan way, cannot fulfill all the hygienic and sanitary requirements for consumption, increasing the risk of microbial contamination (7).

Traditional food-preservation techniques and chemical preservatives have been extensively used to control the growth of food spoilage microorganisms (8). However, synthetic preservatives have been associated with allergic reactions, degenerative diseases, even certain types of cancer $(9,10)$. As an alternative, the use of microorganisms such as
Lactic acid bacteria (LAB) and their antimicrobial metabolites is increasing not only to limit the growth of pathogens and food spoilage but also to improving their shelf life, nutritional, and sensory characteristics $(11,12)$.

Bacteriocins are a family of antimicrobial peptides produced by bacteria through ribosomal synthesis, are active on strains closely related to the producer strain, and sometimes to strains across genera (13). May acts as helper peptides of probiotics strains in the gastrointestinal tract (GI) (14), and some of them have been used as food preservatives, added as purified or partially purified concentrates in pork, fermented milk, cheese, milk, sausage, among other foods (11, 15-17).

Bacteriocins are majorly classified into three classes due to their genetic, biochemistry, and structural diversity (18). The class I, are bacteriocins containing unnatural amino acids inserted as posttranslational modifications. Nisin represents this class, a lantibiotic classified with "generally regarded as safe" (GRAS) status for particular applications by the Food and Drug Administrations (FDA) (19). Class II is the largest and structurally diverse group of bacteriocins, characterized by their high thermostability at broad $\mathrm{pH}$ range. This class contains small $(<10 \mathrm{kDa})$ non-modified peptides, cationics, and highly hydrophobic. Class II is subdivided into class IIa pediocin-like bacteriocins, which share a highly conserved hydrophilic and charged $\mathrm{N}$-terminal part harboring the consensus sequence -YGNGV- and a more variable hydrophobic and amphiphilic C-terminal part. Class IIb two-peptides unmodified bacteriocins, Class IIc circular bacteriocins, and Class IId unmodified, linear, non-pediocin-like bacteriocins. As opposed to Class II, Class III bacteriocins are large, heat-labile structures. Bacteriolytic enzymes as Enterolysin A produced by Lactobacillus crispatus Colicin produced by Escherichia coli belong to this group, as well as non-lytic proteins such as Caseicin 80 and Helveticin J (20).

Bacteriocin identification has been carried out through classical bioprospecting, which involves isolating and purifying the compound for its 
subsequent characterization and validation of biological activity (21). The costs and time necessary for this process, added to the legal limitations associated with access to genetic resources, allow us to consider the use of in silico methods that have been developed in recent decades as an alternative.

Genome mining involves predicting, identifying, and recognizing gene patterns or groups of biosynthetic gene clusters (BGCs), using tools from computational biology and information technology. In this way, it is possible to extract and process the information present in the sequenced genome of an organism, to identify genes that produce a protein of interest $(22,23)$.

Two specialized databases allow predicting putative bacteriocins. The BACTIBASE (24) stores bacteriocins and enables users to predict them using a hidden profile of Markov models, applying as input the primary peptide sequence. The second database, BAGEL 3 is specialized in predict putative bacteriocins in bacterial genomes. Using DNA sequences as input instead of annotated genomes,
BAGEL discovers new bacteriocins through detecting structural genes and genes associated with bacteriocin production (25)which is largely independent of open reading frame (ORF. The purpose of this article is to evaluate the effect of a bacteriocin found by in silico methods on the microbiota present in Antioquian soft cheese.

\section{MATERIALS AND METHODS}

\section{Bateriocin identification}

Screening of reference genome for bacteriocins gene clusters

Draft genomes of eleven strains of Lactobacillus casei available in NCBI genomic database (http:// www.ncbi.nlm.nih.gov/genome/) (January - June 2016), were screened for putative bacteriocins gene clusters using the web-version of BAGEL3 (http:// bagel2.molgenrug.nl/index.php/bagel3). Accession numbers (Table S1) and screening identification workflow are described in the additional (File S1).

Table S1. Accession numbers strains of Lactobacillus casei.

\begin{tabular}{|l|c|c|c|c|}
\hline \multicolumn{1}{|c|}{ Strains } & Assembly access number & Scaffolds & Replicon & Size (Mb) \\
\hline ATCC 27782 & GCA_000224985.1 & - & NC_015975.1/CP003032.1 & 2,0 \\
\hline ATCC 25644 & GCA_000159375.2 & 7 & - & 2,1 \\
\hline WC 1T17 & GCA_900110005.1 & 28 & - & 1,8 \\
\hline DSM 20403 & GCA_900113455.1 & 58 & & 2,0 \\
\hline Zhang & GCA_000019245.3 & - & NC_014334.2/CP001084.2 & 2,8 \\
\hline BL 23 & GCA_000026485.1 & - & NC_010999.1/FM177140.1 & 3,0 \\
\hline BD-II & GCA_000194765.1 & - & NC_017474.1/CP002618.1 & 3,1 \\
\hline LC2W & GCA_000194785.1 & - & NC_017473.1/CP002616.1 & 3,0 \\
\hline 12A & GCA_000309565.2 & - & NZ_CP006690.1/CP006690.1 & 2,9 \\
\hline W 56 & GCA_000318035.1 & - & NC_018641.1/HE970764.1 & 3,1 \\
\hline LOCK 919 & GCA_000418515.1 & - & NC_021721.1/CP005486.1 & 3,1 \\
\hline ATCC 393 & GCA_000829055.1 & - & NZ_AP012544.1/AP012544.1 & 2,9 \\
\hline ATCC 334 & GCA_000014525.1 & - & NC_008526.1/CP000423.1 & 2,9 \\
\hline LcY & GCA_000388095.2 & - & NZ_CM001848.2/CM001848.2 & 3,1 \\
\hline LcA & GCA_000400585.1 & - & NZ_CM001861.1/CM001861.1 & 3,1 \\
\hline
\end{tabular}




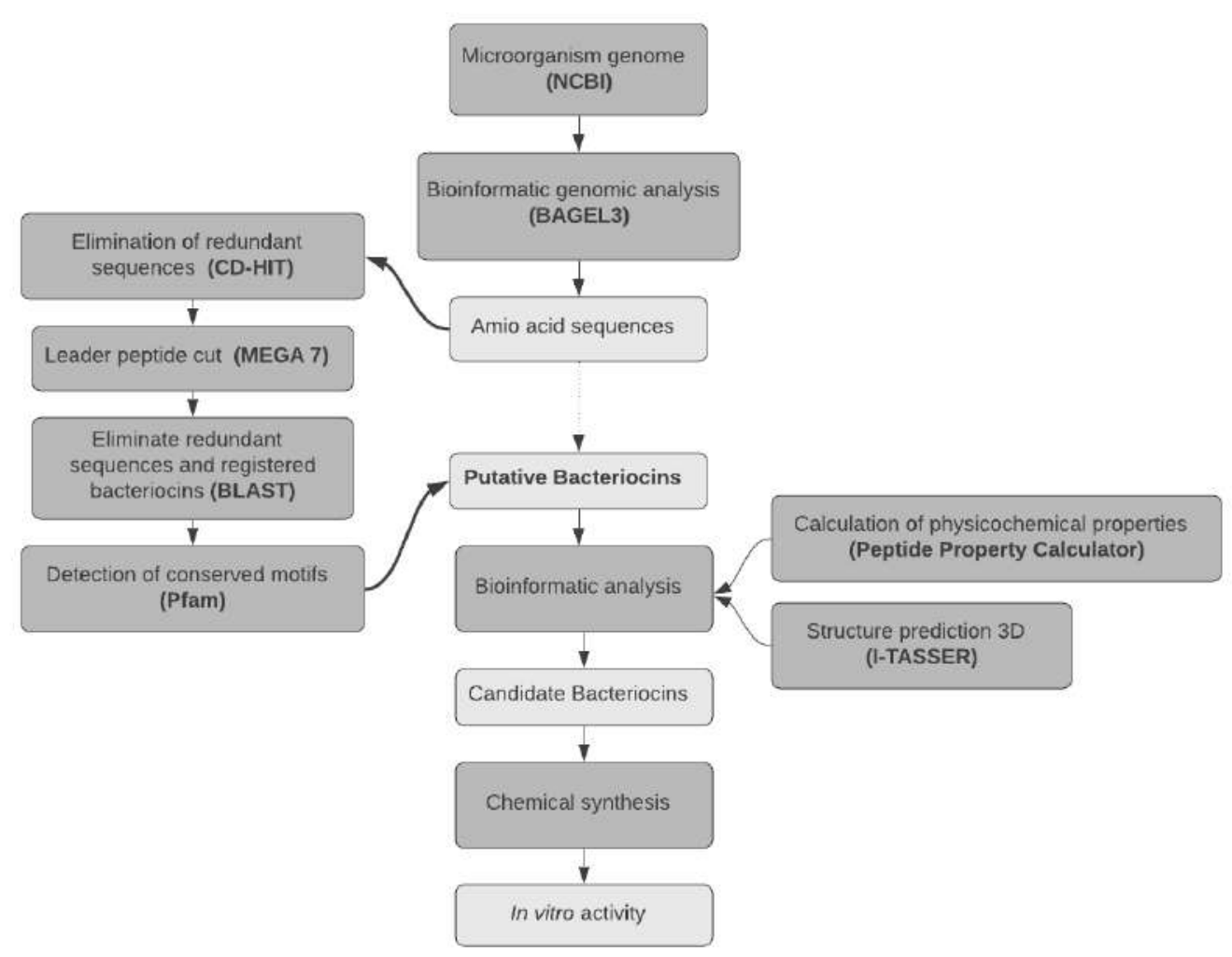

Figure S1: Flowchart

The three-dimensional (3D) structure of putative bacteriocin Bac22 was determined using the I-TASSER server and physicochemical characteristic was calculated with Peptide Property Calculator (www.genscript.com).

\section{Preparation of peptides}

Bac 22 was synthesized by Biomatik (Wilmington, DE, USA), lot number P171107DG241345, manufactured on November 16, 2017 with a purity level the $83 \%$.

Standard solutions of Bac $22(1000 \mu \mathrm{M})$ were prepared in sterile distilled water, considering the molecular weight of the peptide and its purity. This stock was used to prepare diluted solutions with a final concentration of $100 \mu \mathrm{M}$. A commercial preparation of nisin (Nisaplin ${ }^{\circledR}$, Danisco, Grindsted, Denmark), which contains $200 \mathrm{IU} / \mathrm{mL}$ of nisin was prepared following the instruction of manufacturer. This concentration was chosen based on previous tests (data not shown).

\section{Hemolytic activity}

Hemolytic activity of BAC22 was tested upon human erythrocytes (red blood cells RBCs) from a healthy donor. Erythrocytes were separated by centrifugation at $1,000 \mathrm{~g}$ for 7 minutes. The supernatant was discarded, the pellet washed three times and resuspended in $10 \mathrm{~mL}$ of sterile saline solution. Briefly, the test consisted of mixing $90 \mu \mathrm{L}$ of the erythrocyte suspension and $10 \mu \mathrm{L}$ of Bac 22 at concentrations of 100,50 , and $25 \mu \mathrm{M}$, or Nisin at $200 \mathrm{IU} / \mathrm{mL}$. As a negative control (NC), $10 \mu \mathrm{L}$ of saline solution was added to $90 \mu \mathrm{L}$ of erythrocyte suspension, and as a positive control (PC), Triton $\mathrm{X}-100$ at $0.5 \% \mathrm{v} / \mathrm{v}$. The test was carried out by triplicate. The samples were incubated at $37^{\circ} \mathrm{C}$ for 3 hours with constant agitation and then centrifuged at $1,000 \mathrm{~g}$ for 7 minutes. After centrifugation, the supernatant was used to determine the amount of hemoglobin released. Fifty $\mu \mathrm{L}$ of the supernatant of each treatment was added to a well in a 96-well plate, and the absorbance of samples at $545 \mathrm{~nm}$ recorded using a microplate reader (ThermoFisher Scientific, USA). The hemolysis percentage for each sample was calculated using equation 1 . 


$$
\% \mathrm{H}=\frac{\text { Abs Bacteriocin sample-Abs } C N}{A b s C P-A b s C N}
$$

(Equation 1: Percentage of Hemolysis (H \%))

\section{Matrix evaluation}

The antibacterial activity of Bac 22 bacteriocin was evaluated against the microorganisms of the Antioquian soft cheese, a domestic product from Antioquia, Colombia.

\section{Production of Antioquian soft cheese}

Fresh refrigerated raw milk from Paysandú Agrarian Station, a village of Santa Elena, Department of Antioquia, Colombia, was used plus curdling agent and common salt. Soft cheese was made at the Dairy Products Plant of Universidad Nacional de Colombia at Medellin. In Figure 1, the elaboration process of soft cheese is described.

The obtained soft cheese was evaluated under different microbiological tests, such as mesophiles counts, coagulase-positive $S$. aureus, total coliforms, and fecal coliforms; all of them, according to the Colombian Technical Standard NTC 5894. The purpose was to compare the effect of bacteriocins on the microbiological quality of soft cheese, when the peptide was added.

\section{Microbiological analysis}

Soft cheese $(1 g)$ was used for the microbiological analysis. The treatment consisted of adding to the soft cheese, $100 \mu \mathrm{L}(100 \mu \mathrm{M})$ of Bac 22 , or $100 \mu \mathrm{L}$ (200 IU/mL) of Nisin, or $100 \mu \mathrm{L}$ of sterile water as a negative control. Two experimental units of each batch were taken for conducting the microbiological analyzes.

Each packed soft cheese plus the added compound was stored for approximately eight days under controlled conditions at $4{ }^{\circ} \mathrm{C}$. Microbiological sampling was carried out during the storage time following a partially staggered design, starting with an initial sampling at zero time (day zero), day one, day two, the middle of the trial (day four), and at the end of the experiment (day eight).

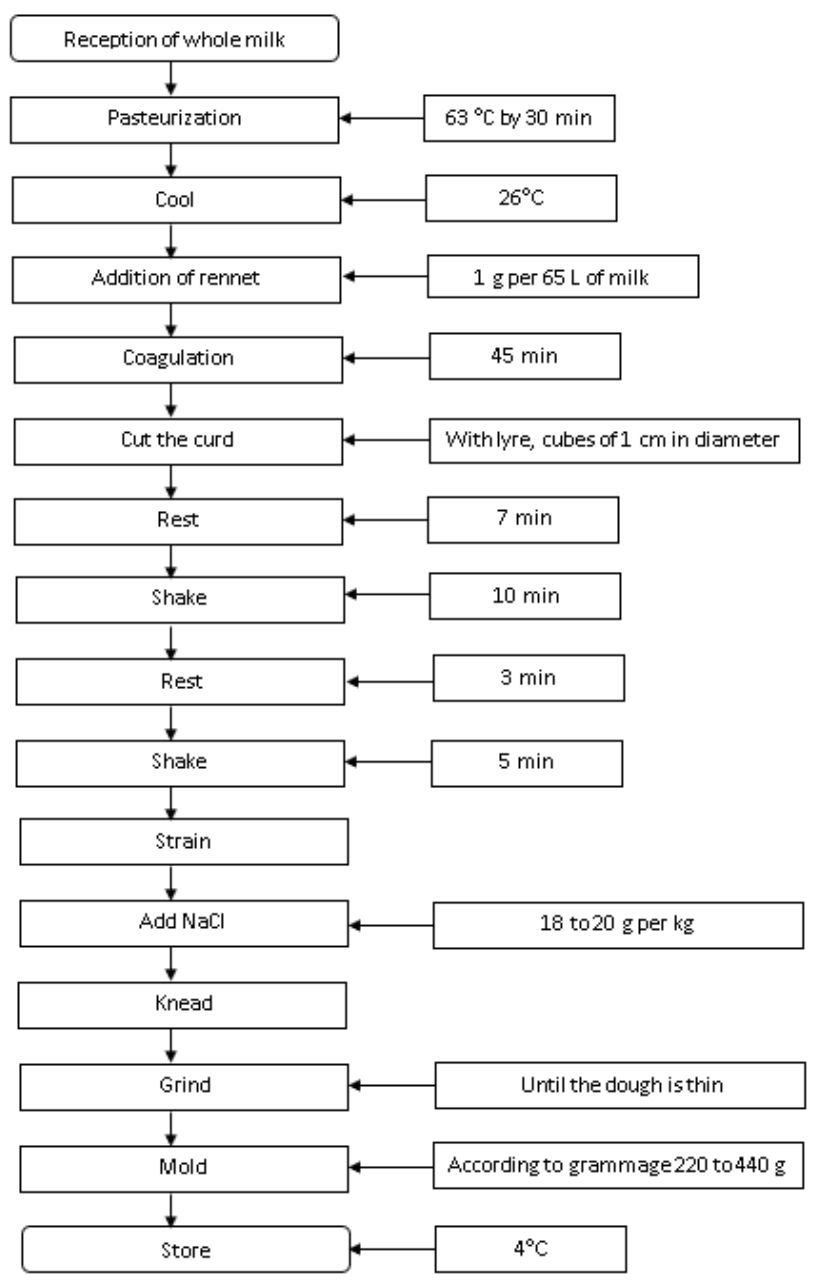

Figure 1. Flowchart of the elaboration process of the Antioquian soft cheese.

\section{UFC / g count of mesophiles}

One gram of soft cheese was added to $9 \mathrm{~mL}$ of sterile $0.1 \% \mathrm{p} / \mathrm{v}$ peptonized water; it was stirred in a Stomacher (Seward, UK) for 1:30 minutes; next, the mix was serially diluted in peptonized water $0.1 \% \mathrm{w} / \mathrm{v}$ until $10^{-4}$. A volume of $1 \mathrm{~mL}$ of each dilution was inoculated in a sterile Petri dishes in duplicate, and then covered it with 12 to $15 \mathrm{~mL}$ of Plate Count agar (Merck, Darmastadt, Germany), they were blended by rotation in an eight movement and waited until solidification. The Petri dishes were incubated at $35^{\circ} \mathrm{C}$ for 48 hours. 


\section{UFC / g count of total and fecal coliforms}

The same procedure, as described before, was followed; however, the dilutions were made up to $10^{-3}$ using Chromocoult agar (Merck, Darmastadt, Germany) and the bacterial cultures were incubated at $35^{\circ} \mathrm{C}$ for 24 hours.

UFC / g count of coagulase-positive Staphylococcus aureus

The same procedure, as described before, was followed. However, from a single dilution, $200 \mu \mathrm{L}$ were taken and inoculated on the surface of Baird Paker agar (Merck, Darmastadt, Germany) in Petri dishes by exhaustion, finally, the petri dishes were incubated at $35^{\circ} \mathrm{C}$ for 24 hours.

\section{Statistical analysis}

Statistical calculations were made using Microsoft Excel (Version 2016). Data were analyzed by two-way analysis of variance (ANOVA) with a confidence interval of $95 \%$ considering statistically significant differences when $\mathrm{p}$-value $<0.05$.

\section{RESULTS}

\section{Bacteriocin identification}

Eight new putative bacteriocins of $L$. casei were identified from its genome using genomic mining (data not shown). Bac22 is a bacteriocin class II produced by L. casei $12 \mathrm{~A}$, which has a short sequence of non-modified amino acids (DSIRDVSPTFNKIRRWFV), a molecular weight of $2,237 \mathrm{kDa}$, an isoelectric point of 11.38 and charge of +2 . Figure 2 shows the three-dimensional structure of the putative bacteriocin Bac22.

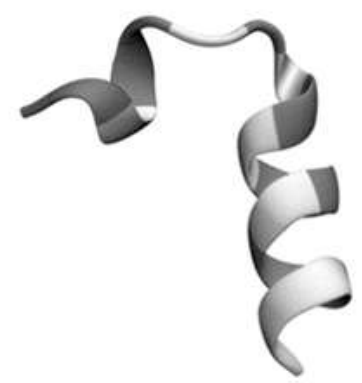

Figure 2. Three-dimensional structure of putative bacteriocin Bac22

\section{Hemolytic activity}

Table 1. Percentage of Hemolysis

\begin{tabular}{|l|c|c|}
\hline \multicolumn{1}{|c|}{ Bacteriocin } & $\begin{array}{c}\text { Concentration } \\
(\boldsymbol{\mu} \mathbf{M})\end{array}$ & $\begin{array}{c}\text { Percentage of } \\
\text { Hemolysis (\%) }\end{array}$ \\
\hline \multirow{3}{*}{ Bac 22 } & 100 & $0.3 \pm 0.1$ \\
\cline { 2 - 3 } & 50 & $0.2 \pm 0.1$ \\
\cline { 2 - 3 } & 25 & $0.4 \pm 0.3$ \\
\hline Nisin & $200 \mathrm{IU} / \mathrm{mL}$ & $0.1 \pm 0.2$ \\
\hline Triton X-100 & $0.5 \% \mathrm{v} / \mathrm{v}$ & 100 \\
\hline
\end{tabular}

\section{Evaluation in the food matrix}

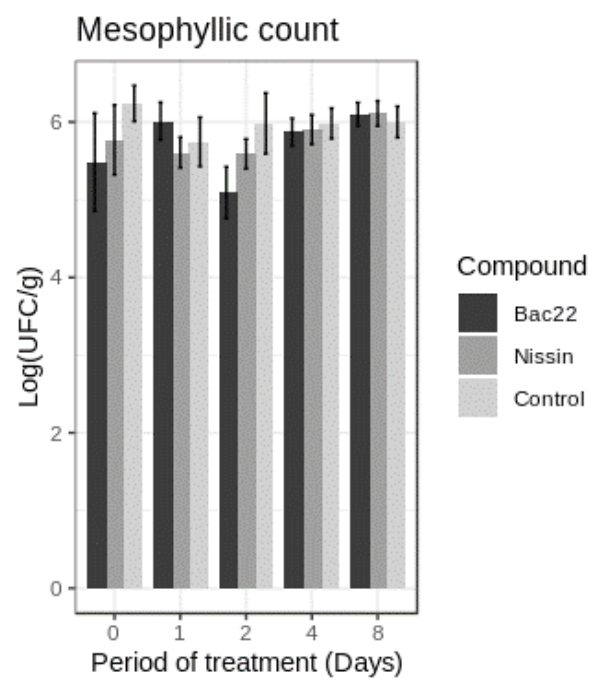

Figure 3. Mesophilic count in Antioquian soft cheese

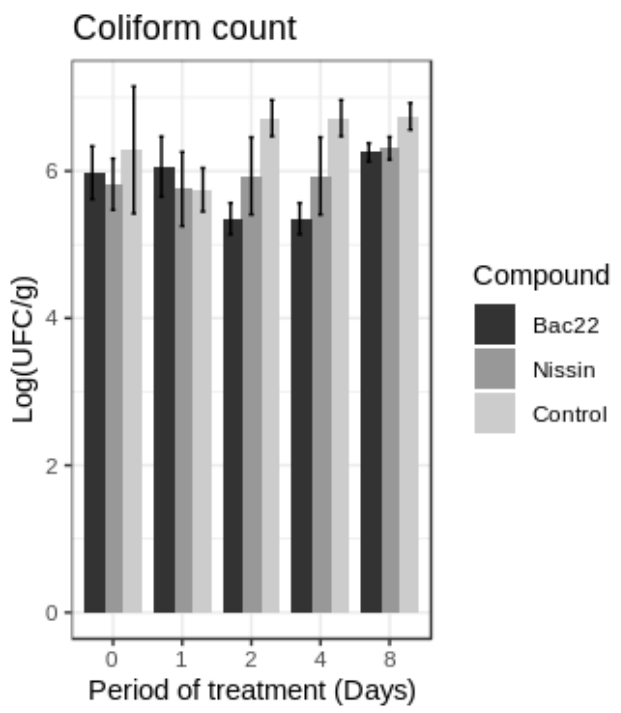

Figure 4. Total coliform count in Antioquian soft cheese 


\section{DISCUSSIONS}

\section{Bacteriocin Identification}

Bac22 is a bacteriocin class II produced by L. casei $12 \mathrm{~A}$ and was identified using bioinformatics tools. Singh and cols (26), using the bioinformatic tool BAGEL 3, classified fifty-two putative bacteriocins across 20 LAB species, that have not been previously reported as bacteriocins producers, and class II was the most predominant. Similarly, Alkhalili and cols (27) analyzed 252 genomes and identified seven putative novel class-I lanthipeptides using BAGEL 3. Oliveira and cols (28) predicted in silico (using BAGEL 3) a putative bacteriocin produced by L. rhamnosus L156.4, and they confirmed the bacteriocin inhibition growth of several bacteria in vitro, including gram-positive human and foodborne bacterial pathogens.

The putative Bacteriocin Bac 22 was selected for in vitro assay due to their high similarity with the bacteriocin $\mathrm{m} 2386$ previously reported by Kuo y cols (29) active against several Listeria species, and because their short sequence facilitates and reduces chemical synthesis costs.

\section{Hemolytic activity}

In the table $1 \mathrm{Bac} 22$ showed percentages of hemolysis of less than $1 \%$ in all its concentrations, including the maximum concentration evaluated $(100 \mu \mathrm{M})$, similar Nisin, which is a bacteriocin for commercial use.

In other studies, carried out with purified bacteriocins of Enterococcus faecalis, no percentages of hemolysis were reported at concentrations of 2 $\mu \mathrm{g} / \mathrm{mL}$ or less, Nisin at $10 \mu \mathrm{g} / \mathrm{mL}$ reported $1.1 \%$ hemolysis in sheep erythrocytes (30). Similarly, in the bacteriocin Aureocin A70 partially purified to a concentration of $1,024 \mathrm{AU} / \mathrm{mL}$ was observed less than $1 \%$ hemolytic activity against sheep red blood (31). These results indicate that the Bac 22 bacteriocin designed in this research does not present hemolysis against human cells, which makes it a peptide with a possible commercial utility.

\section{Food matrix evaluation}

In Colombia, few studies have determined the microbiota of Antioquian soft cheese and how it relates to its preservation. Some authors indicate that combining the effects of bacteriocins with refrigeration, mesophilic aerobic count in white cheeses can be reduced, thus, obtaining a longer shelf life (32).

When evaluating the antibacterial activity of bacteriocin (Figure 3), both Bac 22 and Nisin, on the count of mesophiles in Antioquian soft cheese, did not show significant differences. Where Bac 22 significantly reduced the count of colonies compared to control on days zero and two ( $p<0.05)$. Castro et al., 2009 (33) reported the effect of Nisin on CFU / g count of aerobic mesophiles with a decrease of approximately two magnitude orders (2 logs) in white cheese samples compared to control throughout the treatment. In our case, control was maintained in a stable amount of mesophiles.

In the last days of the test, the mesophil count (Figure 3) does not show differences between the treatments with both bacteriocins and control. It is even observed that the number of colonies is a little smaller compared to time zero. It is known that microbiota present in cheeses, especially LAB, can affect the number of microorganisms in a food system. This kind of bacteria can produce metabolites such as organic acids, like lactic acid, and bioactive peptides like bacteriocins, which lower the $\mathrm{pH}$, and also, they compete for nutrients (34).

Similarly, the total coliform count, no significant differences were observed $(p>0.05)$ in the treatment between Nisin and Bac 22, except for days 2 and 4, where Bac 22 presented a decrease in the total coliforms count. Regarding the control, Bac 22 shows a significant reduction $(\mathrm{p}<0.05)$ in the last days of the test (Figure 4).

Nisin is a bacteriocin that acts mainly over Grampositive bacteria, although previous studies show its effect on some Gram-negative microorganisms such as E. coli (14,35). Castro et al., 2009 (33), obtained the lowest count of coliforms with Nisin added to pasteurized milk before the white cheese elaboration process, indicating that Nisin was more efficient than the use of starter cultures. In the case of Antioquian soft cheese Bac 22, there was a more significant decrease in total coliforms during the treatment.

The microorganism $L$. casei produces the bacteriocin $\mathrm{Bac} 22$, which is part of the microbiota from various dairy products (36). It is possible that due to this, it has a better effect on the microbiota of Antioquian soft cheese. However, investigations are necessary to validate this idea because, to date, 
no study evaluates the microbiota of Antioquian soft cheese and its effect on shelf life.

It should be noted that, in most evaluations of bacteriocins on cheeses, these peptides are added to the pasteurized milk before the coagulation process (38-40). In the present study, bacteriocins were added to the final product due to the small amount of Bac 22 and the large production volumes of the Dairy Plant of Universidad Nacional at Medellín. Future investigations using Bac 22 may be designed considering more available material, which could be added to the cheese before the coagulation process, hoping to obtain promising results like those of this research, and that can be compared with other works.

In all treatments and controls, for the detection of coagulase-positive $S$. aureus and fecal coliform were reported absent during the test, possibly due to good manufacturing practices during the elaboration process of soft cheese, such as good cleaning and disinfection of the equipment.

\section{CONCLUSIONS}

Bac 22 had minimum hemolysis percentages, less than $1 \%$, similar to Nisin, demonstrating that, despite being a synthetic bacteriocin from LAB, it is safe for human consumption. Bac 22 showed a significant reduction over CFU/g of total coliforms concerning Nisin during study time, indicating that it could be a good alternative to be used in the elaboration of Antioquian soft cheese for better shelf life. Additionally, this bioactive peptide could be a conservation alternative for other types of food matrices, including those that contain a high number of total coliforms.

\section{ACKNOWLEDGEMENTS}

To the members of Water and Food laboratory of Universidad Nacional de Colombia for the support provided in tests carried out. To the professor José Uriel Sepúlveda and to the members who work in the Dairy Products Plant of Universidad Nacional de Colombia at Medellín, for the collaboration in the manufacture of Antioquian soft cheese.

\section{CONFLICT OF INTERESTS}

The authors report no conf lict of interest.

\section{AUTHORS' CONTRIBUTIONS}

L.B and P.G conceived the main conceptual idea based on genomic mining. L.B and O.M designed the experiments of biological activity. L.B performed and analyze the results. All authors discussed the results and contributed to the final manuscript.

\section{REFERENCES}

1. World Health Organization. WHO estimates of the global burden of f1. World Health Organization. WHO estimates of the global burden of foodborne diseases: foodborne disease burden epidemiology reference group 2007-2015. World Health Organization. 2015. Available in: https://apps.who. int/iris/bitstream/handle/10665/199350/9789241565165_eng. pdf?sequence $=1 \&$ isAllowed $=y$

2. Guerrero JA. Enfermedades Transmitidas por alimentos. Protocolo de vigilancia en salud pública [Internet]. Instituto Nacional de Salud. 2016. Available in: http://www.hosusana.gov. co/sites/default/files/u1/capacitacion/PRO Enfermedades Trans. por alimentos.pdf

3. Gobernación de Antioquia. SALUDYAMBIENTE - Seccional de Salud de Antioquia [Internet]. 2014 [cited 2017 Nov 6]. Available in: http://diagnosticosalud.dssa.gov.co/0-capitulo-1salud-y-ambiente/pagina-13-capitulo-1-salud-y-ambiente/

4. Asoleche. leche en cifras - Asoleche - Ecosistema Lácteo Colombiano [Internet]. 2018 [cited 2018 Apr 18]. Available in http://asoleche.org/leche-en-cifras/

5. NTC 5894. Productos Lácteos.Queso Fresco ICONTEC [Internet]. 2011 [cited 2018 Apr 19]. Available in https:// tienda.icontec.org/gp-productos-lacteos-queso-frescontc5894-2011.html

6. Sistema Nacional de Salud y Ministerio de Proteccion Social. Evaluación de riesgos de Listeria monocytogenes en queso fresco en Colombia. INS, Ministerio de Salud y Protección Social, Unidad de Evaluación de Riesgos para la Inocuidad de los Alimentos UERIA, Instituto Nacional de Salud. 2011. 67 p. Available in ins.gov.co/Direcciones/ Vigilancia/Publicaciones\%20ERIA\%20y\%20Plaguicidas/ ER\%20LISTERIA\%20EN\%20LPC.pdf

7. Bejarano T EE, Sepúlveda V JU, Correa L G. Elaboración de Quesito Antioqueño reducido en sal, adicionado con Bifidobacterium bifidum y aprovechamiento de este para la elaboración de Queso Fundido. Universidad Nacional de Colombia-Sede Medellín; 2014. Available in http://www.bdigital. unal.edu.co/39672/1/1017175328.2014.pdf

8. de la Fuente M, Barboza JE. Inocuidad y bioconservación de alimentos. Acta Univ [Internet]. 2010 [cited 2016 Nov 23];20(1):43-52. DOI: https://doi.org/10.15174/au.2010.76

9. Agudelo N. Estado del Arte de la obtención de bacteriocinas a partir de bacterias ácido lácticas y su apliación en la industria de alimentos. Pontificia Bolivariana; 2013. Available in https:// repository.upb.edu.co/bitstream/handle/20.500.11912/1409/ Trabajo\%20final.pdf? sequence $=1$

10. Mondragón G, Escalante P, Osuna JA, Ibarra VI, Morlett JA, Aguilar CN, Rodríguez R. Bacteriocinas : características y aplicación en alimentos. Investig Cienc. 2013;21(59):64-70. Available in https://investigacion.uaa.mx/RevistaIyC/archivo/ revista59/Articulo\%208.pdf

11. Balciunas EM, Castillo Martinez FA, Todorov SD, Franco BDG de M, Converti A, Oliveira RP de S. Novel biotechnological applications of bacteriocins: A review. Food Control [Internet]. 2013;32(1):134-42. DOI: https://doi.org/10.1016/j. foodcont.2012.11.025 
12. Camargo I, Gómez S, Salazar V. Impact of bacteriocins and their relevance as preservatives in the food industry. Teoría y Prax Investig [Internet]. 2009;4(2):27-31. Available in: https://dialnet. unirioja.es/servlet/articulo?codigo $=3726666$

13. Alvarez P, Montalbán M, Dongdong M, Kuipers O. Bacteriocins of lactic acid bacteria: extending the family. Appl Microbiol Biotechnol. 2016; 100 (7): 2939-51. DOI: https://doi.org/10.1007/ s00253-016-7343-9

14. López M del R, Rodríguez AI, Chavarría N. LAB bacteriocin applications in the last decade. Biotechnology and Biotechnological Equipment. 2016; 30(6): 1039-50 DOI: https://doi.org/10.1080/1 3102818.2016.1232605

15. Chen H, Hoover DG. Bacteriocins and their Food Applications. Compr Rev Food Sci food Saf. 2003;2:82-100. DOI: https://doi. org/10.1111/j.1541-4337.2003.tb00016.x

16. Perez RH, Zendo T, Sonomoto K. Novel bacteriocins from lactic acid bacteria (LAB): various structures and applications. Microb Cell Fact. 2014;13(Suppl 1). DOI: https://doi.org/10.1186/14752859-13-S1-S3

17. Egan K, Field D, Rea MC, Ross RP, Hill C, Cotter PD. Bacteriocins: Novel solutions to age old spore-related problems? Front. Microbiol. 2016; 7. DOI: https://doi.org/10.3389/ fmicb.2016.00461

18. Kumariya R, Garsa AK, Rajput YS, Sood SK, Akhtar N, Patel S. Bacteriocins: Classification, synthesis, mechanism of action and resistance development in food spoilage causing bacteria. Microb Pathog [Internet]. 2019; 128. (October 2018):171-7. DOI: https:// doi.org/10.1016/j.micpath.2019.01.002

19. Monroy C, Castro T, Fernández FJ, Mayorga L. Bacteriocinas producidas por bacterias probióticas. ContactoS. 2009;73:63-72. Available in http://www2.izt.uam.mx/newpage/contactos/ anterior/n73ne/bacterio.pdf

20. Yang SC, Lin CH, Sung CT, Fang JY. Antibacterial activities of bacteriocins: Application in foods and pharmaceuticals. Front. Microbiol. 2014; 5. DOI: https://doi.org/10.3389/ fmicb.2014.00241

21. Papagianni M, Papamichael EM. Purification, amino acid sequence and characterization of the class IIa bacteriocin weissellin A, produced by Weissella paramesenteroides DX. Bioresour Technol [Internet]. 2011;102(12):6730-4. DOI: https:// doi.org/10.1016/j.biortech.2011.03.106

22. Zerikly M, Challis GL. Strategies for the discovery of new natural products by genome mining. ChemBioChem. 2009;10(4):62533. DOI: https://doi.org/10.1002/cbic.200800389

23. Skinnider MA, Dejong CA, Rees PN, Johnston CW, Li H, Webster ALH, et al. Genomes to natural products PRediction Informatics for Secondary Metabolomes (PRISM). Nucleic Acids Res. 2015;43(20):9645-62. DOI: https://doi.org/10.1093/ nar/gkv1012

24. Hammami R, Zouhir A, Le Lay C, Ben Hamida J, Fliss I. BACTIBASE second release: a database and tool platform for bacteriocin characterization. BMC Microbiol [Internet]. 2010;10(1):22. Available in https://bmcmicrobiol.biomedcentral. com/articles/10.1186/1471-2180-10-22

25. van Heel AJ, de Jong A, Montalbán M, Kok J, Kuipers OP. BAGEL3: Automated identification of genes encoding bacteriocins and (non-)bactericidal posttranslationally modified peptides. Nucleic Acids Res. 2013;41(Web Server issue):448-53. DOI: https://doi.org/10.1093/nar/gkt391

26. Singh NP, Tiwari A, Bansal A, Thakur S, Sharma G, Gabrani R. Genome level analysis of bacteriocins of lactic acid bacteria. Comput Biol Chem. 2015;56:1-6. https://doi.org/10.1016/j. compbiolchem.2015.02.013

27. Alkhalili RN, Canbäck B. Identification of Putative Novel Class-I Lanthipeptides in Firmicutes: A Combinatorial In Silico Analysis Approach Performed on Genome Sequenced Bacteria and a Close Inspection of Z-Geobacillin Lanthipeptide Biosynthesis
Gene Cluster of the Thermophilic G. Int J Mol Sci [Internet]. 2018;19(9):2650. DOI: https://doi.org/10.3390/ijms19092650

28. Oliveira L de C, Silveira AMM, Monteiro A de S, dos Santos VL, Nicoli JR, Azevedo VA de C, et al. In silico Prediction, in vitro Antibacterial Spectrum, and Physicochemical Properties of a Putative Bacteriocin Produced by Lactobacillus rhamnosus Strain L156.4. Front Microbiol [Internet]. 2017;8. DOI: https:// doi.org/10.3389/fmicb.2017.00876

29. Kuo YC, Liu CF, Lin JF, Li AC, Lo TC, Lin TH. Characterization of putative class II bacteriocins identified from a non-bacteriocinproducing strain Lactobacillus casei ATCC 334. Appl Microbiol Biotechnol. 2013;97(1):237-46. DOI: https://doi.org/10.1007/ s00253-012-4149-2

30. Belguesmia Y, Madi A, Sperandio D, Merieau A, Feuilloley M, Prévost $\mathrm{H}$, et al. Growing insights into the safety of bacteriocins: The case of enterocin S37. Res Microbiol. 2011;162(2):159-63. DOI: https://doi.org/10.1016/j.resmic.2010.09.019

31. Fagundes PC, Miceli De Farias F, Cabral O, Santos S, Souza Da $\mathrm{Paz}$ JA, Ceotto-Vigoder H, et al. The four-component aureocin A70 as a promising agent for food biopreservation. Int J Food Microbiol [Internet]. 2016 [cited 2020 Apr 10]; 237:39-46. DOI: https://doi.org/10.1016/j.ijfoodmicro.2016.08.017

32. Heredia C. PY, Hérnández M. A, González C. AF, Vallejo C B. Bacteriocinas de bacterias ácido lácticas: Mecanismos de acción y actividad antimicrobiana contra patógenos en quesos. Interciencia. 2017;42(6):340-6. Available in https:// www.interciencia.net/wp-content/uploads/2017/08/340-01VALLEJO-CORDOVA-42_6.pdf

33. Castro G, Valbuena E, Brínez W, Sánchez E, Vera H, Tovar A. Comparación del empleo de Nisina y cultivos de Lactococcus lactis subsp.lactis para la biopreservación de queso blanco. Rev Cient FCV-LUZ. 2009; 19(2):201-9. Available in http://ve.scielo.org/ scielo.php?script $=$ sci_arttext\&pid $=$ S0798-22592009000200015

34. Zhang H, Cai Y. Lactic acid bacteria: Fundamentals and practice [Internet]. Zhang H, Cai Y, editors. Lactic Acid Bacteria: Fundamentals and Practice. Dordrecht: Springer Netherlands; 2014 [cited 2017 Nov 28]. 1-535 p. Available in https://link. springer.com/content/pdf/10.1007\%2F978-94-017-8841-0.pdf

35. Sobrino A, Martín O. Use of nisin and other bacteriocins for preservation of dairy products. Int Dairy J. 2008;18(4):329-43. DOI: https://doi.org/10.1016/j.idairyj.2007.11.009

36. Douillard FP, Kant R, Ritari J, Paulin L, Palva A, De Vos WM. Comparative genome analysis of Lactobacillus casei strains isolated from Actimel and Yakult products reveals marked similarities and points to a common origin. Microb Biotechnol. 2013; 6(5):576-87. DOI: https://doi.org/10.1111/1751-7915.12062

37. Fuentes M, Londoño A, Durango M, Gutierrez M, Ochoa S, Sepulveda J. Capacidad antimicrobiana de bacterias ácido lácticas autóctonas aisladas de Queso Doble Crema y Quesillo Colombiano. Biotecnol en el Sect Agropecu y Agroindustrial [Internet]. 2017; 15(1):45-55. Available in http://www.scielo.org. co/pdf/bsaa/v15n1/v15n1a06.pdf

38. Dal Bello B, Cocolin L, Zeppa G, Field D, Cotter PD, Hill C. Technological characterization of bacteriocin producing Lactococcus lactis strains employed to control Listeria monocytogenes in Cottage cheese. Int J Food Microbiol [Internet]. 2012; 153(1--2):58-65. DOI: https://doi.org/10.1016/j. ijfoodmicro.2011.10.016

39. Rodríguez E, Calzada J, Arqués JL, Rodríguez JM, Nuñez M, Medina M. Antimicrobial activity of pediocin-producing Lactococcus lactis on Listeria monocytogenes, Staphylococcus aureus and Escherichia coli O157:H7 in cheese. Int Dairy J. 2005;15(1):51-7. DOI: https://doi.org/10.1016/j. idairyj.2004.05.004

40. Soares M, Fernandes A, Carvalho D, Clarissa A, Aparecida A, Souza C, et al. The effects of nisin on Staphylococcus aureus count and the physicochemical properties of Traditional Minas Serro cheese. Int Dairy J [Internet]. 2011; 21(2):90-6. Available from: https://doi.org/10.1016/j.idairyj.2010.08.001 